\title{
Navorsing in Siviele Ingenieurswese aan die Universiteit van Stellenbosch
}

\author{
J.A. van Breda Strasheim \\ Instituut vir Struktuuringenieurswese, Universiteit van Stellenbosch
}

Navorsing in die Siviele Ingenieurswese aan die Universiteit van Stellenbosch word deur die Departement Siviele Ingenieurswese en die Instituut vir Struktuuringenieurswese onderneem.

Die Departement Siviele Ingenieurswese is verdeel in vier afdelings naamlik:

Geotegniek; Projekbestuur en Vervoer;

Hidroulika en Oseanologie;

Struktuuringenieurswese; en

Waterbenutting.

Projekte wat op die oomblik aandag geniet sluit in:

In die Afdeling Geotegniek en Projekbestuur:

Versakking van fondamente op gelaagde kleiafsettings, ondersoeke na die stabiliteit van sekere gronddamwalle in Wes-Kaapland, rasionele ontwerp van spoorbaanformasies, ondersoeke na die gedrag van asfaltmengsels in plaveisels, studies van vervoerpatrone, optimalisering van vastetydverkeerseine, ondersoeke na die geometriese standaarde van klein vliegvelde, en 'n meningsopname onder senior ingenieurs in staatsinstansies, groot munisipaliteite en raadgewende praktyke oor noodsaaklike onderwerpe vir nagraadse studie in die siviele bedryf.

\section{In die Afdeling Hidroulika en Oseanologie:}

Die gelyktydige nabootsing van sedimentvervoer en kusversetting by riviermondings in verwronge hidrouliese modelle, die bagger van swaargruis, golfgeinduseerde snelhede na aan die seebodem, opwekking van onreëlmatige golwe in hidrouliese modelle, aandrywing van boeie met behulp van seegolwe, kragopwekking deur seegolwe, ondersoek na die eienskappe van onderwaterbreekwaters, die bekam- ping van oliebesoedeling in riviermonde, vaartuigaandrywing met behulp van seegolwe, en 'n golfenergieverspiller by die uitlaatwerke vir verkoelingswater by die Koebergkragsentrale.

\section{In die Afdeling Struktuuringenieurswese:}

Torsie op spoorbaandwarslêers en die gedrag van spoorbaanelemente, ruimtevakwerke, plaveiselstrukture oor potensiële sinkgatgebiede, en veselversterkte beton waar natuurlike vesels gebruik word.

\section{In die Afdeling Waterbenutting:}

Verdere ontwikkeling van die loophidrogramkonsep, bepaling van puntneerslagintensiteite vir Suid-Afrika deur middel van isohiëtkaarte, besproeiingsmonitering en -beheer, ondersoeke na die voorkoms van droogtes, en die ontwikkeling van doeltreffende besproeiingsmetodes vir toepassing op skuinsgronde.

Die Instituut vir Struktuuringenieurswese wat gedurende 1976 gestig is se werksaamhede is veral op die gebied van numeriese en rekenaarmetodes van algemene struktuurontleding en -ontwerp toegespits. 'n Omvattende reeks rekenaarprogramstelsels is versamel en selektief bestudeer, verwerk en plaaslik geimplementeer. Die stelsels is meestal oorsee aangekoop en het besondere potensiaal vir die oplossing van probleme in die strukturele meganika, wat nie deur klassieke metodes wat deur ingenieurs aangewend word, opgelos kan word nie. Heelwat klem word op die gebruik van rekenaargesteunde interaktiewe grafiese metodes gelê vir die verwerking van die data met laasgenoemde stelsels.

\section{IUPAC - Internasionale Unie van Suiwer en Toegepaste Chemie}

\section{C.J.H. Schutte}

Dit was ' $n$ baie besige jaar vir die S.A. Nasionale Komitee van IUPAC. Die 13de Internasionale Simposium oor die Chemie van Natuurprodukte is van 2-6 Augustus 1982 by die WNNR-konferensiesentrum gehou. Die simposium, georganiseer deur 'n IUPAC-komitee met dr. J.R. Bull van die Nasionale Chemiese Navorsingsinstituut van die WNNR as voorsitter, was 'n baie groot sukses. Baie buitelandse en Suid-Afrikaanse skeikundiges het dit bygewoon en die lesings was van 'n besonder hoë standaard.

'n Internasionale IUPAC-simposium oor Analitiese Chemie by die opsporing, myn en prosessering van minerale in Suid-Afrika, word van 15-19 April 1985 by die WNNR-konferensiesentrum in Pretoria aangebied. Die simposium sal die volgende velde dek: emissiespektrografie, atoomabsorpsie, $x$-straalfluoressensie, neutronanalise, ioonstraalanalise, massaspektrometrie, oppervlaktegnieke, diffraksie, asook nat chemie.

'n Afvaardiging onder leiding van dr. R.R. Arndt sal die IUPAC-raadsitting in Augustus in Kopenhagen bywoon; ander afgevaardigdes is prof. C.J.H. Schutte, dr. P.S. Steyn en dr. J.R. Bull. 


\section{Prestige internasionale toekenning aan Suid-Afrikaanse mediese wetenskaplike}

Leo Schamroth (59), professor in Medisyne aan die Universiteit van die Witwatersrand en Hoof van die Departement Medisyne by Baragwanathhospitaal, is uit 61 kandidate van 18 verskillende lande as die wenner aangewys van die prestige internasionale mediese toekenning in België vir sy betekenisvolle bydrae tot die vooruitgang van die mediese wetenskap.

Hierdie eenmalige toekenning, wat gemaak is ter viering van die 150 ste bestaansjaar van die "GRAND ORIENT DE BELGIGUE" deur die Vrymesselaarslosie 'LES AMIS DU COMMERCE ET LA PERSÉVERANCE REÚNIS' in Antwerpen, België, was oop vir navorsers van enige mediese dissipline dwarsoor die wêreld-afgesien van ras, kleur of geloof - en was geensins beperk tot Vrymesselaars nie.

'n Internasionale paneel van vyf beoordeelaars het professor Schamroth eenparig as die wenner aangewys.

Dié toekenning, wat uit ' $n$ sieradres, 'n medalje en 'n bedrag van R22 000 ( 1 miljoen Belgiese frank) bestaan, is tydens 'n luisterryke akademiese seremonie in Antwerpen op 27 Mei 1983 aan hom oorhandig.

Onder die 500 uitgesoekte gaste was daar drie Bel- giese kabinetsministers, lede van die Diplomatieke Korps (w.o. die ambassadeurs van die V.S.A. en Nederland) en die hoofraadgewer van die S.A. Ambassade, wat die S.A. Ambassadeur verteenwoordig het.

Die Vise-kanselliers en professore in Medisyne aan al die Belgiese universiteite was ook teenwoordig, asook 'n verteenwoordiger van die invloedryke Max Planck-instituut in Keulen.

Professor Schamroth is 'n internasionaal erkende outoriteit op die gebied van elektrokardiologie en het reeds baie erkenning dwarsdeur die wêreld ontvang as 'n eksentrieke denker, "briljante dosent" (die Lancet), "vakmeester" (American College of Cardiology), wetenskaplike en skrywer.

Sy omvangryke bydrae tot die wetenskaplike literatuur behels meer as 250 publikasies, 10 monografieë en 7 leerboeke, waarvan sommige in Spaans, Italiaans, Duits, Grieks, Japans en Turks vertaal is.

Erkenning is veral gegee vir 14 oorspronklike waarnemings van fundamentele aard wat belangrike deurbrake in die begrip van die elektriese aktiwiteite van die hartspiere meegebring het. 